\title{
IDEOLOGICAL ABSORPTION AND COUNTERTECHNIQUES
}

\author{
COMMENTS ON LINDEMANN
}

Ásta

Tht ARE MASTER NARRATIVES ${ }^{1}$ To use vocabulary that may be
more familiar to some readers, they are part of ideology.
ries that are told in order to explain and justify arrangements. Accompanying them are policing mechanisms, or ideological apparatuses, to keep people in their assigned roles and to keep them from disrupting the arrangements and the justificatory story. Hilde Lindemann's focus in her essay is on what she calls "counterstories" and how the master narratives resist them by absorbing them. Counterstories are ideology critiques aimed at dismantling the justifications that are offered for a certain arrangement or phenomenon by offering alternative and more plausible explanations. The ideological absorption under discussion happens when counterstories are resisted. Lindemann identifies several ways that ideological absorption works, techniques that are used to neutralize the ideology critique. We should not be surprised. Ideology is very resistant. Despite that resistance, Lindemann is hopeful, for she thinks that the success of the \#MeToo movement shows that ideology critiques sometimes manage to get traction and effect change. I am interested in the conditions of success.

Lindemann herself rightly points out that the falsity of master narratives is the crack in the wall that will, with enough onslaught, make it crumble. But that is only the first step in an account of what is required for a successful ideology critique. Drawing on Lindemann's insightful discussion of the various ideological-absorption techniques, I will venture to offer some further steps.

I begin by commenting on features and functions of four of the techniques

1 I am delighted to get a chance to comment on Hilde Lindemann's essay, "Counter the Counterstory." I have learned so much from Lindemann's work and been deeply moved by it.

2 Althusser, "Ideology and Ideological State Apparatuses"; Geuss, The Idea of a Critical Theory, 81 . 
Lindemann discusses: make the language pretty; play devil's advocate; play "What about Me?"; and require victims to be blameless.

\section{MAKE THE LANGUAGE PRETTY}

As an example of making the language pretty, consider calling attention to domestic violence as part of a critique of an ideology that sees women as for use by men. The ideological resistance involves redescribing domestic violence as "domestic disputes" as a way to absorb the criticism and deflect it: what happened within the walls of a private house has nothing to do with societal values and norms; it is not systematic. It is merely individuals disagreeing, or at most behaving badly.

The function of this instance of making the language pretty is to deflect from the systematic nature of the phenomenon and to write the injustice out of the story.

\section{PLAY DEVIL'S ADVOCATE}

An example of this technique is when we resist the ideology that has it that people who are poor are so because they are lazy by pointing out that many people who live below the poverty line are actually working more than one job and still cannot make ends meet. This is where the technique comes in. The interlocutor then offers an alternative explanation "just for the sake of argument" of why people may be poor, instead of engaging in the counternarrative. This alternative explanation, again, lays the blame for poverty on the individuals and their choices. As with make the language pretty, this technique functions to deflect from the systematic nature of the phenomenon and lay the blame on individuals and their choices.

\section{PLAY “WHAT ABOUT ME?"}

This technique shifts the conversation back to the dominant group. Consider men's groups organized around the possibility that a man might be falsely accused of rape. Instead of talking about sexual violence of women, they shift the conversation back to themselves and the possibility that they may be falsely accused. Another example of this technique is when a mansplainer feels guilty about having mansplained and all the energy goes to making him feel better instead of attending to what he did. I take the function of this technique to keep 
the limelight always on the member of the dominant group and not give the member of the oppressed group equal standing.

\section{REQUIRE VICTIMS TO BE BLAMELESS}

Examples of this technique are when a woman is raped and someone says that she was asking for it because her skirt was too short. This sort of technique resists the charge that an injustice took place by pointing out features of the victim or their history that are seen as in some way blameworthy. Then, since they are blameworthy for those features, they deserved what they got. I see this technique as in line with an ideological defense that blames whatever happens on the victim's own choices and behavior and denies any systematic injustice. Moreover, since the focus is squarely on the victim and their behavioral history, it also prevents us from seeing the continuity between their predicament and ours. They are the bad apple. Bad things happen to bad apples, not to good ones. We are safe.

\section{5. \#METOO}

Why has the \#MeToo movement had the success it has? Lindemann herself suggests that what accounts for the success is the number of shots fired, given that the ideology is false. And that is certainly part of it, but more is required.

Naming. Having hermeneutical resources to describe the phenomena is key, as all consciousness-raising groups know. People get together and discuss their experiences and collectively develop linguistic and conceptual tools to identify phenomena that are harmful to them. The \#MeToo movement relies on feminist work and activism around sexual harassment and sexual violence that has taken place since the seventies. This work has involved coming up with linguistic and conceptual tools, educating others about the phenomena, and fighting for legislative and social improvements.

Acknowledging systematicity. Recognizing the pervasiveness and the systematic nature of sexual harassment and sexual violence is another essential element. A precondition for that is having the words and concepts to name and describe the phenomenon, of course, but then we need to be able to spot the phenomenon when we encounter it, and acknowledge it. Here, facing shame is essential. And we face shame by realizing the systematic nature of the phenomenon and that we, individual people, are not the ones to blame. Great risk can be involved in stepping forward and owning that a certain harmful thing has happened to you. This is why small signals of solidarity, whether they be pink ribbons to show solidarity with breast cancer survivors or hashtags such as \#MeToo, play a large 
role: they lower the risk in coming forward and, therefore, enable more people to do so. Only then does the systematic nature of the phenomenon become visible. And only then do we see the continuity between our predicament and those around us. Victims are not bad apples. Othering victims cannot keep us safe. We can only be safe if we join together.

The above steps, naming and acknowledging systematicity, are important. But what do we do next? We need to resist the ideological apparatuses and absorption techniques in action. We need to identify the phenomena when they happen, and armed with an understanding of how these techniques function, disable their functioning. Lindemann's essay is part of that work. The techniques she identifies give us tools to resist: we recognize that a certain maneuver is being made and understand the function and effectiveness of that maneuver. Feminist work, both popular and philosophical, offers us tools to identify ideological apparatuses of this sort. For example, recently Rebecca Solnit has made the concept of mansplaining part of popular culture in the United States. ${ }^{3}$ It is not only a concept that helps us make sense of our experiences, but it also makes us spot certain power differentials at work around us (think of observing a heterosexual couple on a first date where the man talks at the woman for hours). Similarly, Kate Manne has offered us the concept of down girl moves, which are ideological apparatuses to put women in their ideological place. ${ }^{4}$ Both of these are cases of informal apparatuses, but laws or regulations can also keep people in their place, as can their material effects. ${ }^{5}$

Resistance requires not only alternative explanations, or counterstories, for the oppressive arrangements we live with. It also requires that we attend to the ideological apparatuses and techniques that help maintain the status quo and find ways to resist them. Lindemann's discussion of the various techniques of ideological absorption are part of that work. Drawing on that work, we can develop countertechniques. For example, when someone calls a case of domestic violence a "domestic dispute," we can insist that mere disputes do not involve being beaten unconscious. When someone plays the devil's advocate, we can say, "That is an interesting theory, but let's linger on the fact that people working two or three jobs cannot make ends meet." When someone wants to turn the light back onto the dominant group by considering the possibility that a man may be falsely accused of sexual harassment or rape, we can insist on keeping the light on the victim. And when the victim is required to be blameless, we can point

3 Solnit, Men Explain Things to Me.

4 Manne, Down Girl.

5 The interplay between the ideological and the material cannot be ignored, but I am not attending to that here. 
out that what happened to them is completely out of proportion to whatever they supposedly did that could be blameworthy (we can also contest the blameworthiness of some of those things as well, such as wearing a short skirt). Even an eye-for-an-eye account of just punishment has the thief who steals a pack of Marlboros suffer the equivalent of a loss of a single pack of cigarettes, not three rounds of bullets to the stomach. ${ }^{6}$

Using countertechniques such as the ones above is an act of ideology resistance and can, in turn, result in sanctions. It can be uncomfortable to behave badly (ideologically). And it certainly is unpopular with those invested in the status quo. But there are areas where such deliberate ideology resistance is, and has been, effective. For a current example, we can think of bystander training as training in countertechniques to fight oppressive ideologies. The point of bystander training is not so much to convince the person who is spouting false ideological explanations or policing others, but to dismantle the effectiveness of the narrative or policing mechanism. We may not be able to change everyone's mind, but we can empower those around us to resist the ideology with us. And there is strength in numbers. ${ }^{7}$

\section{San Francisco State University asta@sfsu.edu}

\section{REFERENCES}

Althusser, Louis. "Ideology and Ideological State Apparatuses." In Lenin and Philosophy and Other Essays, translated by Ben Brewster. London: New Left Books, 1971.

Geuss, Raymond. The Idea of a Critical Theory: Habermas and the Frankfurt School. Cambridge: Cambridge University Press, 1981.

Lindemann, Hilde. "Counter the Counterstory: Narrative Approaches to Narratives." Journal of Ethical and Social Philosophy 17, no. 3 (June 2020): 286-98. Manne, Kate. Down Girl: The Logic of Misogyny. Oxford: Oxford University Press, 2017.

Solnit, Rebecca. Men Explain Things to Me. Chicago: Haymarket Books, 2014.

6 These are all examples of countertechniques. The reader may think of others that may be more effective.

7 I thank the editor, Mark Schroeder, for helpful comments on this essay, and Hilde Lindemann for an inspiring piece. Naturally, I am the only one responsible for the views herein and any remaining errors. 